\title{
УOBОЗНАВСТВO. NITEPATУPOBHABCTBO
}

\author{
УДК 811.161.2'367.622'28(477.86/.87+83) \\ DOI https://doi.org/10.24919/2308-4863/35-6-12
}

\begin{abstract}
Наталія ХІБЕБА,
orcid.org/0000-0003-1098-3082

кандидат філологічних наук, дочент,

доиент кафедри українського прикладного мовознавства

Львівського національного університету імені Івана Франка

(Львів, Україна) khibeba@ukr.net
\end{abstract}

\section{СЛОВОЗМІНА ІМЕННИКІВ У СУЧАСНИХ БОЙКІВСЬКИХ ГОВІРКАХ}

Незворотні зміни на різних мовних рівнях говору мотивують потребу вивчати граматичну структуру діалекту як можливість окреслити перспективи щцодо його функціювання та висвітлити низку загальномовних проблем.

Статтю присвячено вивченню морфологічних діалектних особливостей бойківських говірок. Зокрема проаналізовано словозміну іменників у ї̈ динамічі від кіния XIX cm. до сучасного формотворення, щчо актуально з огляду на потребу иілісно дослідити граматичну будову изих говірок.

На підставі зібраних сучасних діалектних текстів із Бойківщини, доступних етнографічних $і$ фольклорних матеріалів, діалектологічних джерел середини 50-60-х років XX ст. можна дійти висновків, щзо іменникова словозміна в бойківських говірках зберегла особливості діалектного формотворення, незважаючи на експансивний вплив літературної мови та контактних говорів, передусім наддністрянського.

Відзначено розгалужену флексійну систему іменника, збереженість архайчних закінчень (передусім у парадигмі множини), рідкофіксоване діалектне формотворення чи не фіксоване (утрачено маркувальні морфологічні явища для бойківських говірок, зокрема закінчення -оў у Н. в. одн. іменників ж. р., -ум у Д. в. мн.; -и - в О. в. мн. тошо). Виявлено високий ступінь варіантности словоформ, зумовлених впливом літературної мови, діалектних закінчень однієї відміни на іншу, закінчень твердих основ іменника тощз, продуктивність фонетично видозмінених закінчень, тенденцію до поширення нормативних закінчень. Із-поміж закінчень, які збігаються з літературними, у деяких відмінках переважає нормативне, а в інших - діалектне: давні закінчення домінують, витісняючи навіть нові. Часто виявлено дублетні словоформи в мовленні одного говірконосія: діалектне та закріплене літературною нормою закінчення.

Ключові слова: бойківські говірки, формотворення, словозміна, іменник, відмінок, закінчення.

Nataliia KHIBEBA, orcid.org/0000-0003-1098-3082 Candidate of Philological Sciences, Associate Professor, Associate Professor at Department of Ukrainian Applied Linguistics Ivan Franko National University of Lviv (Lviv,Ukraine) khibeba@ukr.net

\section{WORD-CHANGE OF NOUNS IN MODERN BOYKIVSKIY DIALECTS}

Irresistable changes on different language levels of speech stimulate the need to study the grammatical structure of the dialect as an opportunity to define prospects for its functioning and highlight a number of common language problems.

The article is devoted to the study of morphological dialectal features of Boykivskiy dialects. The word-change of nouns in their dynamics from the end of the XIX century to modern formation is analyzed, which taking into account the need to integrally research the grammatical structure of these dialects.

Based on collected modern dialect texts from Boykivshchyna, available ethnographic and folklore materials, dialectological sources of the mid 50-60s of the XX century one can come to conclusion that the noun word-change in Boykivskiy dialects has preserved the peculiarities of dialectal formation in spite of the expansive influence of literary language and contact dialects, especially Transnistrian.

The attention is paid to ramous flexion system of the noun, the preservation of archaic endings (especially in the paradigm of the plural), the rarely fixed dialectal formation or the non-fixed (marking morphological phenomena for Boykivskiy dialects, in particular endings -ö̌ in Nominative case singular feminine gender, $-\boldsymbol{y} \boldsymbol{M}$ in Dative plural, $\boldsymbol{- \boldsymbol { u }}$ in Ablative and many others) are lost. A high degree of variability of word forms due to the influence of literary language, dialectal endings of one declension to another, endings of solid noun bases, etc., productivity of phonetically modified endings, tendency to spread of normative endings are revealed. Among the endings that coincide with the literary ones, 
the normative ones prevail in some cases, and the dialectal ones in other: the old endings dominate, displacing even the new ones. Duplicate word forms are often found in the speech of one speaker: dialectal and fixed by the literary norm ending.

Key words: Boykivskiy dialects, formation, word change, noun, case, ending.

Постановка проблеми. Незворотні зміни на різних мовних рівнях говору мотивують потребу вивчати граматичну структуру діалекту як можливість окреслити перспективи щодо його функціювання та висвітлити низку загальномовних проблем. Об'єкт дослідження - морфологічні особливості сучасних бойківських говірок, зокрема словозміна іменника.

Аналіз досліджень. До аналізу залучено передусім діалектні тексти, які записано польовим методом у бойківських селах Львівщини й ІваноФранківщини впродовж 2004-2009 pp. (див. мережу обстежених населених пунктів ${ }^{1}$ ), а також праці, присвячені вивченню морфологічних особливостей бойківського говору. Морфологічні риси говірок Турківського району досліджував Д. Бандрівський (Бандрівський, 1959), словозміну іменників аналізувала I. Ощипко (говірки Турківського, Старосамбірського та Сколівського районів) (Ощипко, 1971). У контексті дослідження бойківського говору питання про його морфологічні риси висвітлювали в монографіях та окремих розвідках I. Свєнціцький (Свєнціцький, 1913), С. Рабій-Карпинська (Рабій-Карпинська, 2011), I. Жилко (Жилко, 1955), Д. Бандрівський (Бандрівський, 1960), С. Бевзенко (Бевзенко, 1980), I. Матвіяс (Матвіяс, 1982), М. Яким, М. Зубрицька (Яким, Зубрицька, 2002; Зубрицька, 1992) та ін. Морфологічні особливості бойківських і лемківських говірок за матерілами пам'яток VI-VII ст. аналізував I. Керницький (Керницький, 1971).

Водночас використано інформацію 3 тих населених пунктів Бойківщини, висвітлену на картах «Атласу української мови» (АУМ), «Загальнослов'янського лінгвістичного аталсу» (ОЛА), «Атласу бойківських говірок» (AGB), у матеріалах до «Мовного атласу Галичини» (ММАГ). 3 метою простежити динаміку формотворення іменників бойківських говірок від кінця XIX ст. використано етнографічні, фольклорні матеріали (Гнатюк, 1908; Кміт, 1908; Княжинський, 1934; Кузеля, 1908; Левинський, 1908; Мисевич, 1937; Рошкевич; Schnaider, 1911, 1912), діалектні тексти 50-60-х рр., уміщені в збірникові «Говори української мови» (Говори:

\footnotetext{
1 Детально про говірки Богородчанського району ІваноФранківської области див.: Хібеба Н. Фонетичні особливості бойківських говірок Рожнятівщини. Вісник Запорізького наиіонального університету. Серія «Філологічні науки». 2020. № 1. Ч. II. C. $65-76$.
}

240-243), та записи діалектологічних експедицій із сіл Коростів і Бориня Львівської області (Матеріали; Матеріали ${ }^{1}$.

Мета статті - окреслити систему словозміни іменника в бойківських говірках на підставі аналізу власних діалектних записів та опрацьованого матеріалу.

Виклад основного матеріалу. Іменники ж. p. І відміни 3 м'якою основою у Н. в. одн. мають літературне закінчення -a: тазди́н'а (Бк, Гл, Лп), молоди́и'а (Лб, Мл), пшени́и'а (Бк, Вч, Дн, НГс, СНб) тощо; у говірках порубіжжя - зрідка - -i: тазди́н'i (Рc), молоди́и'i (Бг, ВСт, Ям), пшени́и'i (Бг), коси́и'i (Бг, Глбк, Мж, НГс) // коси́и'а (Глбк, Ксм, Мж), -е: пров'ідни́и'е (ВСт) та ін.; пор.: бойк. фа'сол'а, наддністр. - фа'сол'i, фа'сол'е, фа'сол'и (Матвіяс, 1982: 48); див. також Рабій-Карпинська, 2011: 70; ОЛА, 6 ФГ: F(SM) 3400; FP 2217; FP 2205; ОЛА, 6 ЛС: F(SM) 1081; ММАГ, 124, 139, 517; детально див.: Хібеба, 2000; Хібеба' ${ }^{1}, 2000$.

В іменниках с. p. роду домінує закінчення -a: жит'á, кам'ін'а, бажа́н'а, воло́с'а, з'ілл'а, уззут'á, вес'їл'а́, зак'інчен'а, хо́джен'а, шч'а́с'm'a, n'íрйа, подв 'ірйа тощо (див.: Рабій-Карпинська, 2011: 70), окрім бойківських говірок порубіжжя, на які значно впливають наддністрянські говірки: волос'e, волос'i (Тр, Нб), жит'е́ (Уp), запитан'е (Тp), мотутузі (Сл), n'ípüe (Рc), сва́maн'e (Дб), u'y'ес'm'e (СНб) тощо (детально див.: Хібеба, 2020).

У збірних іменниках поширене закінчення -a: бpám'a (Вч, Гл, Дн, Лп, Мл, НГс, Ос, Трл, Ур, Ям) // рідко бра́m'i (Бг, Гл, Дб, Кз, Ксм, Тр); пор.:

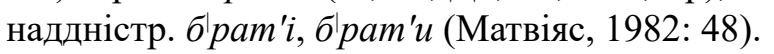

Форм іменників ж. р. на кшталт бри́тов 'бритва', це́рков 'церква', го́лов 'голова', хуруго́в 'корогва' у Н. в. одн., які були поширені в бойківських говірках як їх маркувальна морфологічна риса [(абій-Карпинська, 2011: 70; AGB, VII (2): 80; Радевич-Винницький), не виявлено; як і форм: плато́в 'платва', станов 'кадь' (стіни прості) (вид діжки з рівними, невигнутими боками) (с. Вовче) (ММАГ: 32, 65), пор.:

Наші сваха старосту взєла за бороду

Та повела го в воду,

Пісочком го терла,

Бритовщев підголила (Левинський, 1908: 116).

Записи від кінця XIX ст. фіксують іменник иерков у Н. в. (Мисевич, 1937: 33) та 3. в.: прийдуть передъ церковь (Кузів, 1889: 285); у сучасних діа- 
лектних текстах виявлено: О. в. n’id це́рквоў (Дб), пе́ред ие́рквойу (Уp), М. в. у иеркви́ (Оc).

Засвідчено діалектні відмінності форм числа іменника: То не було́ / йак типе́р'к'i m'i кремпл'їни // кос'т'у́ми то йа́годами на́тими чо́рними кра́сили / мал'ува́ли / аби́ так не б 'іл'ілос'а // йак типе́рки с'а уббе́ре мужик у н'ейло́нову соро́чку $i$ ка́же / пус'm' уссегда́ бу́d'ет со́ние // а йакшо́ уубе́ре полотн'а́ну соро́чку / йак вйїде на полонинну i ка́же / пов 'í̆ / в 'ímpe / на Ўкрайіну / бо його́ гр'і́ло то // а за́раз тот'ї нейло́ни не гр'і́йут (Кр); Макаро́ни / ото́ / йак мака́йем у бул'йо́ни / то макаро́ни з йу́шкоу уже (Ур), Даўно́ не бу́ло таки́х ро́скош'ій / йак

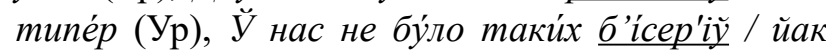
на Іва́но-Франк'йушчин'i / ше дес' (Лб), I не бу́ло тих н'і иукро́вих d'iабе́т'іү̆ / н'ійако́го ши'а́ка (Мт), Були́ лаўки́ та шос' там пр'аде́ // тут пати́ка с кло́чами / пов'ісмо (Кр); Ну / так / йак типе́рка // ру́ж'ами таки́ми висо́кими // то́же с папе́р'ї̌̆ (Oc) та ін., а також: з жалосточків, на жалості (Рошкевич: 78, 85).

Подекуди зафіксовано неузгодженість роду іменника із залежними словом: Було́ аш n'iзн'їме // спекли хл'і́ба уу сво́йім печи́_i ўс'о (Лс), А́ле гро́ш'i

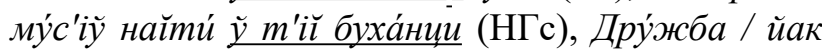
захо́диў до ха́ти / тотий па́лии'оў / шо маў у рука́x / хрести́у водв 'ірйа (Бк) тощо.

У Р. в. одн. архаїчне закінчення -е в обстежених бойківських говірках збереглося в іменникові день: дне (Уp), дн'е (СНб) // дн'а (Бк, Зв, СНб, Трл); Мен'ї усе с'і здайе́ / шо то бу́ло дру́гого дн'е у молодо́zо / бо то с'i не могли́ спра́вити // ma / дри́гого дн'e / йа зна́йу / шо то бу́ло два дни вес'їл'а (СНб), Чи то́го дне ўночи́ ра́но $i$ йшли до то́йі ўже до молодо́йi ўс'i го́с'm'i (Ур); дет. див.: Свєнціцький, 1913: 125; Рабій-Карпинська, 2011: 71, 90, 99; Бандрівський, 1959: 3; Бандрівський, 1960: 53; Радевич-Винницький; також: 50-го дне по Пасиі (Кміт 1936: 85), форми Р. в. одн. іменників ч. р. на -е, незалежно від того до яких основ вони належали (дне, колодязе, манастире, ступене тощо), засвідчено в пам'ятках XVI-XVII ст. із території Бойківщини (Керницький, 1971: 407).

Архаїчних форм Р. в. одн. на -е іменників с. p.-t-, -n- основ і ж. p. -и्र- основ (племене, любве, иркве, крове та ін.), засвідчених у вчительних євангеліях із території Бойківщини (Керницький, 1971: 405), у сучасних говірках не виявлено.

У Р. в. іменники ч. р. часто засвідчено із закінченням -а: дво́ра́ (Дб, Тр) (дво́ру (Лс)), ка́мен'а (Бк), сúpa (Бк, Зв, Іл, Мт, Ор, Рс, Яв), стола́ (Дб), nоро́za (Вч, Іл, Лс, Яв) тощо (див.: Рабій-Карпинська, 2000: 70, 99; Воронич, 2000).
Іменники сучасної III відміни у Р. в., Д. в., М. в. одн. послідовно зберегли історичне закінчення -и: ма́тери (Гл, Лп, Лс, НГс, Трл), сме́рти (Яв), со́ли (Вч), по л'убо́ви (Трл), при зу́стр'ічи (Ур), у nечú (Вч) // y̆ nечý (Вч), па́м'imu (Pc), па́мйати (Кр, Лк, Лс), па́мн'ати (Глбк, Кз, Кр, Ор, Рс, Тр) // náмйат'i (Кр, Лб) (говірконосії молодошого віку) (див.: Ощипко, 1971: 174; АУМ: к. 174, 175); у записах кінця XIX ст.: банности, радости, печи (Кузів, 1889: 282, 283, 300), уфности, нинависти (Кміт, 1936: 85), по сїножьати (Кміт, 1908: 89), смерти (Мисевич, 1937: 33); а також: банно́сти, радо́сти (Матеріали), 'осини (Нб) (Говори: 310 ). Збереження відмінювання давніх *1-основ характерне для південно-західних говорів (Ощипко, 1971: 174; АУМ: к. 174, 175).

У Д. в. одн. іменники ч. р. незалежно від кінцевого приголосного основи мають закінчення -ови: ба́m'кови (Вч, Лб, НГс, СНб, Тр, Яв), в'іти'о́ви (Яв), д'ітвако́ви (Бг), Миха́йлови (Нб) (М'iхайл'óв'i (Бк)), си́нови (СНб, Ур), та́тови (Бк, Кз, Рс, СНб, Трл), хл'ібови (Сл), чолов 'ікови (Трл, СНб) тощо; ця флексія за аналогією до форм ч. р. поширювалася й на іменники с. р. (дет. див.: Рабій-Карпинська, 2000: 71, 89, 99-100; Бандрівський, 1959: 4; Ощипко, 1971: 173; Воронич, 2000; Радевич-Винницький; АУМ: к. 177, 178, 179); див. ще в записах від кінця XIX ст.: єгомосиььови, коникови, свекрови (Кузів, 1889: 285, 286, 320), Богойко́ви, Іва́нови, ксьиндзойкови (Гнатюк, 1908: 19, 26) Богойкови, тосподарьови, єтомосиььови, старостойкови (Кміт, 1908: 88, 92, 95), господарьови, дворови, столови, татойкови, яворови (Кузеля, 1908: 127, 137, 144), зборови, татови (Левинський, 1908: 106, 108), дякови, попови (Мисевич, 1934: 24), żudowy (Schnaider, 1911: 158), tatowye (Княжинський, 1934: 16), а також: л"нови (Бт) (Говори: 306).

Спорадично зафіксовано й закінчення -еви: го́стеви (СНб), хло́пиеви (СНб) // хло́пиев’i (СНб, Лc, Ос); а також: господареви (Кузів, 1889: 301; Левинський, 1908: 116; Мисевич, 1934: 21); це закінчення переважає в східнобойківських говірках Долинського та Рожнятівського районів (АУМ: к. 178, 179).

У деяких іменниках збережено давнє закін-

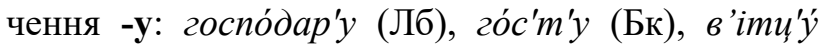
(Лп, Трл), па́ну (Вч), па́ну в 'imu'ý (Трл), Бо́гу (Лб), Го́сnоду Бо́zу (Вч, СНб), хло́nu'y (Вч) тощо. Як паралельне до -ови закінчення -y характерно для говірок Турківщини (АУМ: к. 177).

Діалектні тексти ілюструють, що досліджуваним говіркам здебільшого властиві нормативні закінчення Д. в. одн. ч.р., а саме: -ов'i: бám'ков'i 
(Бк, НГс, Трл), бра́mов'i (Лп, Лс, Мт, Тш), в'ітчи́мов'i (Pc), ви́йков'i (Лб, Рс), д'і́ов'i (Вч), Іго́рков’i (Крш), кс'о́ндзов'i (Оc), мужико́в 'i (Кр), ону́ков'i (Крш), све́кров'i (Кр), свекро́в’i (Oc), синнов 'i (Кр, Ор, СНб, Яв, Ям), с'в 'ішче́ников 'i (Pc), стрийо́в'i (Лб), хло́пчиков ’i (Кр, Ур), та́тов ’i (Бк, Вч, Дб, Дн, Зв, Кр, Лк, Рс, Сд, Трл, Тш, Шм, Ям); -еві: госпо́дарев'i (Бк, Вч), коне́в'i (СНб). АУМ фіксує закінчення -ов'і (братові, батькові, женихові) оказіонально в говірці с. Бітля (// -у) (АУМ: к. 177, 178), закінчення -ев'і (товаришеві, злоdiєвi) - у говірці с. Жупани Сколівського району (// -ови, -у) (АУМ: к. 179).

В аналізованих говірках спорадично засвідчено форми Д. в. одн. із прийменником $\partial, i \partial, \kappa: I \kappa c^{\prime} о н д з$ йі зно́ву веде́ к поро́гови і приведе́ к престо́лови (Oc), Ко́жна гу́ску д ха́m'i несе́ (Ксм), А друшк'ú с колаче́м в 'іхо́d'ат д дружба́м (Ксм), Несу́m' тот'i ж'інки д ха́m'i d'ímuм б'їлого хл'іба (Ксм), які часто фіксовані в етнографічних записах бойківського весілля кінця XIX - поч. XX ст.: Ой вила, перевивала, Д серденьку прикладала; Присьлїдили вни ї Д'зеленому яворови (Кузів, 1889: 282, 318), д'серию (Кміт, 1908: 83), д’столу припадати, д'серденьку (Рошкевич: 78, 103); Ой рад же бь я встати, ІІ свойому дїтяти; Й а спусти мене нижи, Д сирі землиии ближи; Не боком, Аннице, не боком, А й id Василькови с притоком; Ой наш любий Васильку, Приступи к столойкови; к столойкови, к вінойкови (Кузеля, 1908: 124, 129, 130, 16). Відзначили такі конструкції в бойківських говірках I. Ощипко (Ощипко, 1971: 171), у говірках Старосамбірського району - Я. Пура (Пура, 1960: 173).

В О. в. одн. іменники ж. р. мають закінчення -оў, -еў: бу́л'боў (Кр), водо́у (Зв), голово́ў (Нб), дити́ноў (СНб), д'і́ўчиной (Дн), доро́гой (Ос), дру́шкой (Дн), ж 'інкоў (Кр), кра́йкоў (Глб), Ма́ткоў Бо́жоў (Ул), ма́моў, ми́зикой, сва́хоў (Кр), (Кр), ни́ткой (Ур), позл'іткоў (СНб), сли́ноў (Крш), соро́чкоў (Оp), ф' ’іроў (Oc); води́иеу (Oc), коси́иеў (Глб, Ксм, Мж), мате́р'іиеуеу (Лб), молоди́цеу (СНб) тощо; а також іменники ч. р.: дру́жбоў (Кр) (дру́жбом (Pc)), ста́ростоў (Ул); див. ще: таздоў, Касунейкоц̆, коно́ўкоў, ма́т'інкой, роди́ноў, соро́чкоц̆ тощо (Гнатюк, 1908: 14, 15, 28; Кміт, 1908: 92; Кміт, 1936: 85; Кузеля, 1908: 131, 133; Кузів, 1889: 286, 301, 319; Левинський, 1908: 102, 104, 112, 117; Мисевич 1937: 24, 46; Рошкевич: 85, 94, 97, 107, 115; Schnaider, 1912: 150, 152; Матеріали; Говори: 241, 245).

Із закінчення -оў вживаються також іменники м'якої групи: пшени́щ'оў (Кр, Лб) // пшени́цеў (Бк, Вч, Іл, Ксм, Лс, СНб, Ур, Яв), па́лии'оў (Бк) // náлицееў (Вч, Іл, Трл) // náлицейуy (Вч); карти АУМ свідчать про перевагу в бойківських говірках формотворення типу зем'леў, долонеў, душеу // душоў (АУМ: к. 170, 171), закінчення -еў характерне для говірок центральної Бойківщини (AGB VII (2): 80; m. 408); дет. див.: (Рабій-Карпинська, 2000: 71; Бандрівський, 1959: 4; Ощипко, 1971: 171-172; Воронич, 2000; Бевзенко, 1980: 227; Матіїв, 2013: 8).

Закінчення -уў (варіант -оў) засвідчено в іменниках ж. р 3 твердою основою: Бра́лос'а сло́йік / ба́нка трил'ітро́ва / тро́шк'е л'е́нтуў приздоби́ли / шоби́ не бу́ло так стра́шно вигл'ада́ло ітам кида́ли туда́ (Лб), Гор'їуккуц тоди́ так с'а не занима́ли (Сл), Чи систри́ в 'ін с те́тоў n'íшле / чи з вй́̆нуў (Oc) тощо; див. ще Зубрицька, 1992: 18; -иў (варіант флексії -еў) - в іменниках ж. p. із м'якою основою: То жи́том / то пшени́ииў / то жи́том / то пшени́йй / то ўс'а́коў йарини́циц̆ (Бк).

Також відзначено нормативні закінчення -ойу в іменниках твердої групи: господа́ркойу, гор'іллкойу (Лc), д'їуччинойу (Кз, Лс), дру́шкойу (Бг), л'е́нтойу (Мж), нев 'істойy (НГс), ста́ростойy (СНб), старос'и'інойу (Лс), сок'и́ройу (Лк), тар'і́лкойу (Глб, НГс), шкаралу́пойу (Сд), шпи́л'койу (Лс) та ін.; та м'якої -ейу: грани́цейу (Лс), інформа́и'ійейу (Лб), ку́хнейу (ВСТ), мате́р'ійейу (Лс), молоди́цейу (Кр, СНб), n'існейу (НГс), пшени́цейу (СНб) та ін.; також: зорою (Кузеля, 1908: 136).

Записи поч. XX ст. фіксують неузгодженість y закінченнях іменників i залежних від них прикметників і займенників, а саме: Чирвонов калиною За своєв дїтиною (Кузеля, 1908: 142), 3 біленьков ручечкою, Іс шісьтьом, із здоровком; С повнов повненькою Із лїса виїздит, Д' селу приїздт (Левинський, 1908: 105, 119).

Іменники ч. р. та с. р. роду з м'якою основою та $з$ основою на шиплячий ж, $ч, w$, дж в О. в. одн. уподібнюються до іменників твердої групи: ба́л'u'ом (Вч, Кр, Трл, Ур), вес'іл'о́м (Бк, Вч, Дб, Іл, Кз, Кр, Лб, Лк, Лс, Рс, Трл, Ур), вес'іл'ом (Дн, Кз, Кр, Трл), в'ін'и'ом (ВСт), в'ін'и'о́м (Дб, НГс), водв 'ірйом (Бк), г'ілл'ом (Мл), го́с'm'ом (Гл), дн'ом $(\mathrm{HГc),} \mathrm{дождж́́} \mathrm{(Вч,} \mathrm{Гл),} \mathrm{зб'южом} \mathrm{(Гл,} \mathrm{Лс,} \mathrm{Ул),}$ к’нн'йо́м (Лс), кон'о́м (Лб), корова́йом (Вч, Тр), коровайо́м (Вч, Глбк, Крш, Лс, Рп), корогвайо́м (Лп), ма́ршом (Бк), маршо́м (НГс), моз'іл'о́м (Лб), ножо́м (Кр, Лс, Рп), па́рчом (Лб, Лп), пле́чом (Тр), пе́ри'ом (Вч), пе(u)рu'о́м (Вч, Лп), плас'u'о́м (Ур), подв'ірйом (Вч), пропо́йом (Лс), ри́жом (Трл), се́рия'ом, сон'йом (Вч), топ 'ір'й'ом (Кр), ч'іпи'о́м (Іл, Лб) та ін.; а також: пириьом, сириьом (Кузів, 1889: 300), гільтайом, коньом, крамарйом, польом, периьом (Гнатюк, 1908: 12, 13, 20, 28), гостьом, 
коньом, периьом, сериьом (Кміт, 1908: 86, 96, 95), гребіньиьом, Дунайом, каміньом, пириьом, серцьом, соньцьом, оконьцьом (Кузеля, 1908: 126, 131, 139), тонтьом, здоровйом, зєтьом, крайом, татунцьом, щзістьом (Левинський, 1908: 103, 108, 115, 117, 119), Спасительом, вітиьом (Кміт, 1936: 84-85), барвінойом, Михальом (Мисевич, 1937: 16, 31), с пропо́йом, n’id ба́л'u"ом (Матеріали), n'im чәпй"о́м (Матеріали'). На форму -омь у бойківських говірках як похідну від -bмь, -ъмъ звернув увагу ще І. Свєнціцький (Свєнціцький, 1913: 124; див. ще: Рабій-Карпинська, 2001: 71, 101; Ощипко, 1971: 173-174; Воронич, 2000; Радевич-Винницький; АУМ: к. 180, 185).

У говірці с. Опака Дрогобицького р-ну та с. Гвіздець Старосамбірського р-ну, як зафіксувала С. Рабій-Карпинська, виявлено варіант закінчення -ом - -ум: пал'u'yм, вікоेн ${ }^{\prime} u^{\prime} y^{o} \mathcal{M}, x^{\prime} л о п u^{\prime} y^{o} \mathcal{M}$, $m u^{e} л^{\prime \prime} a m^{\prime} y м$ та ін. (Рабій-Карпинська, 2001: 89, 101), а також варіанти - -ім, -им у прикладах: напо́йім (Оc), хло́пи'iм (Трл), папе́рим (Нб).

Закінчення -ем в іменниках із м'якою та шиплячою основою здебільшого засвідчене в східнобойківських говірках Рожнятівського району, а також у смузі перехідних говірок Богородчанщини: в'інще́м (НГс), греб'інце́м (СНб), дереўце́м (СНб), йайие́м (Мж), колаче́м (Бг, Ксм, Мж), колач'е́м (Сл), коровайе́м (Бг, Рп), ноже́м // ножо́м (Лс), плече́м (Бг, Мж), обруче́м (СНб) (Рабій-Карпинська, 2001: 101). АУМ фіксує в бойківських говірках закінчення -ем як варіант до -ом (дош'чем) у говірках сіл Суходіл і Ясень Рожнятівщини (АУМ: к. 180), а форми с. р. роду ('полем, 'серием) - у говірках Долинського та Рожнятівського районів (АУМ: к. 185).

Зазначмо, що в мовленні одного говірконосія можуть виступати різні засоби формотворення: Йічте / бойа́рие / йiчте / чи с пери'о́м / чи не с пе́рu'ем (Вч).

За аналогією до іменників ж. p. І відміни іменник мати в О. в. одн. набуває закінчення -оў (варіант -уў): мámeроў (Вч) (Кл'ака́ŭym пéped мám'ipyy̆ $i$ ка́жут (Яв)), молод'о́жуў (Лб) (А да́л'ще iз yc'iмá d'iўчám'iмa / з молод'о́жуў); інші іменники III відміни мають форми: зе́лен'y (Уp), ска́терт'y (Op), ше́pc'm'y (ВСт) тощо (Рабій-Карпинська, 2011: 71, 100-101; Бандрівськи, 1959: 4-5; Ощипко, 1971: 175). АУМ фіксує в іменниках колишньої -г̆- основи закінчення -ец // -оц̆, у говірках Сколівського та Долинського районів - y; оказіонально в говірці с. Жупани - ейу ('солейу, 'm'інейу, 'ночейу) (АУМ: к. 176).

У М. в. одн., як і в Д. в., іменники ж. р. I відміни 3 м'якою основою та 3 основою на шиплячий звук мають закінчення -и (// -i): $\check{y}$ Бережни́щи (СНб), ў д'іжи (Глбк), ў Йамел'ни́щи

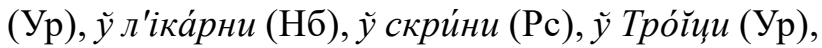
на ву́лиции (Крш, Тр), на у́лиции (Кр), на ла́вици (Oc), на поли́ци (ВСт, Трл), на сn'і́дници (Іл, Лc), уу сп'ін:ищи (Лб) тощо; у записах від кінця XIX ст.: свекрищи (Кузів, 1889: 320; Кузеля, 1908: 143), в столици, в сьвітлици, в дебрици, в иерковци, на земли, на полици, при кирници (Кузів, 1889: 282, 285, 286, 302, 317), Гануси, Каси (Гнатюк, 1908: 20, 21), при водици, при кирници (Кузеля, 1908: 124), на межи, в церковци (Левинський, 1908: 108, 110, 112), w Łyроwycy (Schnaider, 1911: 160); а також: ўми́л'ници (Матеріали), по зем'ли, на'тәрниции (Яс) (Говори: 306). Закінчення -и в М. в. одн. іменників колишніх -ја- основ (земля, рілля) типове не тільки для бойківських говірок, а й загалом для південнозахідного діалекту (АУМ: к. 172); формотворення на гlруши засвідчено в говірках Сколівського, Турківського (с. Лімна та с. Лосинець) (// на гіруши'i), Долинського (с. Вишків) районів (АУМ: к. 173); див. також: (Рабій-Карпинська, 2011: 100; Ощипко, 1971: 171; Матіїв, 2013: 8).

Закінчення -и зафіксовано в іменниках II відміни 3 кінцевим м'яким і шиплячим звуком: $y$ Йа́сени (СНб), ў Терно́поли (Мж), на к’інций (Oc), на (уу) м’іссии (Вч, Лс), на таре́ли (Крш), ў Б'їличи (Pc), на лиции (Мж, Лк), на плечи́ (Кр, Лб, СНб); а також: в сїдельии, на камени (Кузеля, 1908: 84, 133, 149; Левинський 1908: 107), в мори, при сьтільичи (Левинський, 1908: 107, 111). Закінчення -и мають топонімні назви ч.р. із суфіксом -ів: $\check{y}$ Ла́годови (Pc), у Хашчо́ви (Лп), на Воро́ви (УЛ), в 'і Л'во́ви (Вч), а також засвідчено: ў в 'іни (Вч), на база́ри (УЛ), на иъви́нтари (Лп), по хус'm'ámи (Лб).

Паралельно фукціює закінчення -у: $y$ бе́резн'y (НГс), y з'іл'ý (Яв), у Закарпа́m'y (Іл), у пла́m'y (Op), у прим'ішчен'y (СНб), у ти́жн'y (Кр), на вес'íл'y (Бг, Бк, Вч, Іл, Кз, Лб, Лп, Лс, Нб, НГс, Рс, СНб, Яв), по вес'їл'y (Кр), на кло́ч'y (Лк), на кам 'íн'y (Бк), на подв 'íp'y (Вч), на со́н'u'y (Лб, Лс), по в 'ін'чан'y (Вч); у говірці с. Багнувате Турківського р-ну - y' 'ісі'аu'y (АУМ: к. 182); див. ще: (Бандрівський, 1959: 5; Ощипко, 1971: 174).

Закінчення -и мають іменники із суфіксом -еи': y̆ буха́нци (НГс), ў горо́дции (Сл), ў гориии (Трл), y та́нцฺи (НГс), ў ч’iпuиu (Вч, Іл, Лп), на (у) в інщии́ (Дб, Лб, СНб, Тр, Ям), на хл'ібции (Лб, Глб, Ксм), при (на, у) к'інци́ (Вч, Дб, Кз, Кр, Лб, Ос, Сл, СНб, Яв), ў ба́л'ųu (Кр, Лб) // ў ба́л'u'y (Гл, НГс); також: в гории (Кузів, 1889: 316), в чіпици, в віньици (Кузеля, 1908: 137, 145). Це закінчення в іменниках чоловічого та жіночого роду з основою на [ц] засвідчено 
в усіх бойківських говірках Львівської та ІваноФранківської области (АУМ: к. 182).

Іменник по́ле у М. в. одн. має давнє закінченням -и (у більшості говірок): То на по́ли // йак прийили до молодо́zо (Вч), Ой ги́л'а-ги́л'а по по́ли гу́сси (Яв), У по́ли пом'ічни́и'у (Яв) // -i: Чоти́ри си́ни у по́л'i ора́ти (Крш, Ор) // -у: А у нас йе по nóл'y pocmé (Кр), А йа дайý ста́іку там і там на так'íм по́л'y (Лб); а також: по поли (Левинський, 1908: 105, 115).

Закінчення -ови в Д. в. одн. властиве іменникам ч. р. із суфіксом -ок: по к'ел'е́шкови (Вч), по куско́ви (Бг, Вч, СНб), по кусо́чкови (СНб, Мж), а також: по бо́дакови (Яв), по стакано́ви (Нд), по чолов'ікови (Трл) (Рабій-Карпинська, 2011: 72, 101; Бандрівський, 1959: 5); у говірках сіл Верхня Яблунька та Рибник - 'уубови (АУМ: к. 181). В іменниках с. p. цього закінчення не засвідчено.

$\mathrm{y}$ записаних діалектних текстах виявлено безприйменникове формотворення М. в. (див. ще: Свєнціцький, 1913: 125; Рабій-Карпинська, 2011: 72, 101):

А шчо йа с'а молоди́іка так понев 'ip'áŭу // йака́с' б'і́да г вигада́ла / шчо не ма́йу ро́ду / та бо у ме́не т'їл'ко ро́ду иі'ілий ро́чок хо́ду // йе́дно Лйnйа / дру́zе Би́ćmpe / а тре́те Михно́ви / де четве́рте $\check{l}$ Лопуша́нка / а пйати́í $\check{y}$ Хамчо́ви (Лп);

Верни ся дївойко,

Кличе тя матїнойка.

Десь ключі подївала,

Щось скринї замикала?

У горичи на полици

Молодші сестричи (Кузів, 1889: 302).

Пісенний фольклор в обстежених говірках засвідчує нормативні закінчення Кл. в. одн. Зокрема здрібніло-пестливі іменники ж. р. на -а мають закінчення -у (м'яка основа): А́н'и'y (Бк, Вч), Га́н'y (Рс), Ганусу́н'y (Яв), до́н'y (Бг, Мж), ма́ми'y (Вч, Гл, Яв), Ма́мйу Бо́жа (Лп), мату́с'y (Кз), Mapúc'y (Лб), сваху́н'y (Лс), та ін., див. ще: мамунцюю, Марисуню (Левинський, 1908: 102, 111), а також -о (здебільшого тверда основа): городниччко, д'іброво́йко, д'іуучино́н'ко (Вч), дити́н'ко (Лп), д'іти́нко (Яв), зозуле́н'ко (Шм), мат'іно́йко (Яв), ма́мко (Бг, Глбк, Кр, Лк, Мж, Сд), мат'інко (Лп, Рс, Шм), ма́т'інко (Дб, Шм), Маруси́но, Мар'ійе́чко (Вч), сестри́чко (Глбк, Сд) та ін.; пор. ще: Kác'o (Бк), ма́мų'o (Лп), свахуно́йкy (Лc). І. Ощипко зазначила, що в бойківських говірках назви істот, зокрема осіб, часто мають у Кл. в. закінчення -о незалежно від роду іменника й кінцевого приголосного (Ощипко, 1971: 172; див. ще: Рабій-Карпинська, 2011: 71; Бандрів- ський, 1959: 5), що й підтверджують досліджувані діалектні тексти; див. також: дівойко, Марисейко, матінко, матїнойко, родинойко, тещейко (Кузів 1889: 283, 284, 285, 287, 300, 302; Гнатюк, 1908: 15, 20, 23; Кміт, 1908: 91; Кузеля, 1908: 127; Левинський, 1908: 103, 111; Schnaider, 1912: 145; Княжинський, 1934: 19; Рошкевич: 74, 76), а також: ба́бо (Вч, Яс), тзди́н'o (Вч), нана́шко̂ (Дв, Тп) (ММАГ: 59), ма́т'інко, д'іти́нко, А́нно, во́дон'ко (Матеріали).

Іменникам II відміни зі здрібнілими суфіксами -к-, -ок-, -очок-, -ечок- тощо властиве закінчення -у: барв'іно́чку (Лб, Лп), в'інку (Ксм), в 'іно́чку (Дб), м'іс'аче́н'ку (Лк), М'іхайло́чку (Вч), парубо́чку, сва́тку, та́тойку (Бк), татуне́чку (Вч), Бо́жейку (Гл) // Бо́жец̌ко (Рc) // Бо́гойку (Бк, Вч, Шм), а також: сúнy (Шм), mámy (Бк, Вч, Гл, Дн, Іл, Кз, НГс, Ос, Рп, Сл, Тр, Шм, Яв, Ям), cвámy (Глбк); у записах від кінця XIX ст.: Богойку, Иваночку, конічійку, сватку, старостойку (Кузів, 1889: 282, 284, 285, 286, 287, 306, 318), Божейку, вінойку, Іванойку, татойку (Гнатюк 1908: 12, 15, 19, 16, 20), барвінойку, Божейку, татунейку (Кміт, 1908: 86, 87, 90), Васильку, татойку (Кузеля, 1908: 124, 128), батеньку, місєчку (Левинський, 1908: 105, 114), Василечку, городчику (Рошкевич: 75, 81).

Закінчення -у характерне для іменників м'якої групи: бра́u’':y (Бк, Лп), господа́p'y (Трл), йáceн м'ic'аи'y (Лс), йетомо́с'и'y (Яв), Івану́н'у (Яв), корова́йу (Вч), корогва́йу (Ксм) татуниу́н'у (Лп), а також: синьйю (Кузеля, 1908: 128), ие́еннарйу (Гнатюк, 1908: 16), татунц̧ю (Левинський, 1908: 104), Дани́л'и'y (Матеріали); див. також Ощипко, 1971: 174.

Пестливі форми іменників ч. p. із закінченням -о у Кл. в. часто мають форму Н. в. (здебільшого в пісенному фольклорі): брати́н'ú'o, тати́н'ú, старосту́н'о: Мо́вит брату́н'úo / мо́вит / най т'а Б’之г благосло́вит (Лп), Мо́вит тату́н'и'o / мо́вит

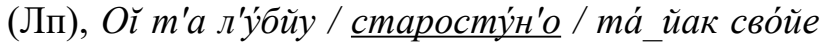
се́рuе (// старосту́н'y) (Шм), а також: музиче́(ú) йко, старосто́йко, татуне́йко, татуне́чко:

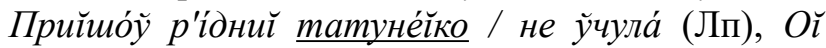
каза́ў_ис ми / м'ій татуне́іко / шчо ми не даш в'ід себе (Лп), Прийшо́ў р'і́дий татуне́чко та й гла́dит (Бг), Ой музи́ко / музичи́йко / гра́йеш весели́іку

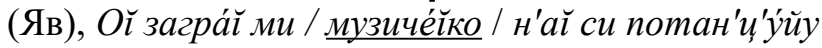
(Лп), Бода́ ́ то́б’ $i$ / старосто́йко / голова́ обл'іззла (Яв) та ін.; а також: старостойко, дружбойко (Кузів, 1889: 282, 284, 287).

У Називному в. мн. збережено архаїчне закінчення -е в іменникові л'у́де (Вч, Гл, Дн, Кр, Крш, Лб, Лп, СНб, Трл) (майже скрізь - л'у́де (Ониш- 
кевич, I: 422), АУМ фіксує слово в говірках сіл Лімна, Верхня Яблунька, Тур'є, Підліски, Суходіл, Плав'я (АУМ: к. 190), а також: бойа́рие 'весільні гості нареченого' (Вч), прида́не 'весільні гості нареченої' (Бк, Вч, Дн, Лп, Трл), прида́нще 'тс.' (Вч), цига́не (Лп); див. ще: бояре, боярие, горяне, люде, придане (Кузів, 1889: 284, 285, 286, 287, 302, 318), льу́де, сусьі́де (Гнатюк, 1908: 14, 18), бояре (Левинський, 1908: 115, 118; Рошкевич: 93), 'л'yде (Яс) (Говори: 307),

Вчуют нас горяне:

От їутьь бояре.

Учуют нас Сльвівие:

От їдут Дидївие (Кузів, 1889: 302).

Закінчення -ове виявлено в іменниках, засвідчених у фольклорних текстах: л'удоико́ве (Вч), свато́ви (Глбк, Мж), свато́ви (Бг), а також у 3. в.: Зна́йіте / с'і́ли за тисо́в 'i сто́ли / за пшени́чн'i хл'ібо́ви (Вч), див. ще: людейко́ве, людко́ве, людове, лютко́ве (Онишкевич, I: 422; Матіїв, 2013: 263), боярове, хлїбове (Кміт, 1908: 89, 90, 95), сватове, хлїбове (Кузеля, 1908: 127, 148), газдове, нанашкове, хлібове (Кузів, 1889: 282, 300, 301), сут таздове і таздині (Кміт, 1936: 85), столове (Рошкевич: 82). Флексію -ове в іменниках Н. в. мн. ч. р. у пам'ятках XVI-XVII ст. із теритоpiї Бойківщини також часто вжито в назвах тварин і предметів (волове, пташкове, садове) (Керницький, 1971: 404; дет. див.: Свєнціцький, 1913: 125; Рабій-Карпинська, 2011: 72, 89, 101; Бандрівський, 1959: 5; Ощипко, 1971: 176; Воронич, 2000; Радевич-Винницький).

Форми Н. в. мн., набуваючи відтінку збірности, виступають у значенні Кл. в.: Простуn'iu'a / дyдойкове / то да́їте нам по́л'a / то н'ай ше си погул'а́йе ўс'а роди́на мо́йа (Вч).

Іменник в 'ін'ции (Мж) (із суфіксом -к у Н. в.) зберігає давню форму Н. в. мн. на кшталт паропии, нив'ірници, 'воуци (Рабій-Карпинська, 2011: 101-102). Араїчні форми іменників ч. р. на -и у Н. в. мн. зі збереженням давнього переходу $[г]>[3],[\kappa]>[ц],[\mathrm{x}]>[\mathrm{c}]-$ одна 3 рис карпатської групи говорів (Бевзенко, 1980: 225; див. ще: Керницький, 1971: 404).

Іменники ч. p. м'якої основи засвідчено із закінченням -и: бойа́рии (Дн), к’йн'ии (Oc), проп'іййи (СНб, Яв), хло́nџ̧и, ч'і́ици (Лп), дни (Бк, Вч, Дб, Кз, Лк, Лп, Сд, СНб, Трл, Тш), а також: бояри, пропійции (Кміт, 1908: 87; Кузеля, 1908: 148), пропійции, веселовичи (Кр) (Матеріали).

Іменник вість -ї основи у Н. в. мн. зберігає

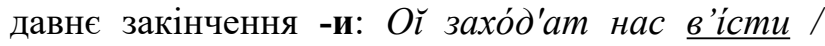

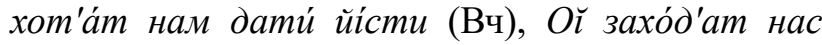
sв 'ícmu / хот'ám нам дати́ йісти (Лп); див. ще: вісти (Кузів, 1889: 300; Гнатюк, 1908: 25; Кузеля, 1908: 126, 148; Левинський, 1908: 113); а також: за́nов'idu (Вч, Іл, Кр, Лс, Мт, Трл, УЛ, Яв), за́пов'idu // за́пов'id'i (Вч, Яв): Пото́м на за́пов'idu йили дава́ти // у сел'і́ с'в'ішче́ника не було́ / аж на Іса́йі йіздили ми ф' 'іроў / там дали́ на зánов 'id'i (Яв). Закінчення -а у Н. в. мн. в обстежених говірках є рідкісним (Зубрицька, 2012: 22) і $є$ варіантним до -и: хл'іби́ (Іл, Кр) // хл'ібá (Трл): Нa вес'іл'á браў ка́ждий сво́йе хл'іба́ (Трл) (детально про фонетично видозмінені закінчення Н. в. мн. див.: Хібеба 2020; Хібеба $\left.{ }^{1}, 2000\right)$.

У бойківських говірках за аналогією до форм Р. в. мн. іменників ч. р. закінчення -іў поширюється й на іменники жіночого роду: баб'ㄷу (Бг,

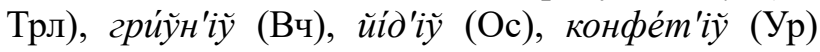
(конфе́тиў (Бк)), коро́н'іў (Уp), л'е́нт'iў (Бг, Гл, Мл), n'ic'н'iy̆ (Тр), ру́ж' $і y$ (Гл), сва́x'ïy (Кз, СНб, Ур), сва́шк'iy̆ (Іл), се́стр'іў (Іл, Нд), скринн'іў (Рс),

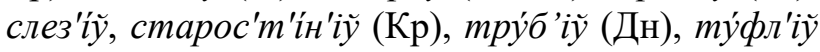
(СНб), ша́ф'iў (Трл, Ур) та ін.; рідко - нульова флексія - конфе́т (Яв), маши́н (Дб, Кз, Лб, Мл), n'iсе́н' (Кр), сук'ено́к (Дн): Та то бога́то так йе

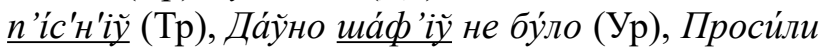

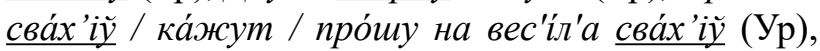
А ра́н'че коро́н'ійне бу́ло (Ур), Нав'ішувалилее́нт'їу та уус'а́ких ри́ж'іў (Гл), Ў нас не би́ло три́б'iy̆ // munép idým ў клуб (Дн), Та йіх бу́ло пйат' cécmp'ǐ̆ i йіде́н брат (Нд), Типе́р не́ма тих скри́н'іў (Pc),

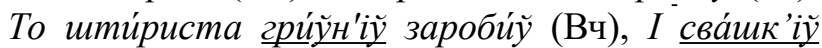

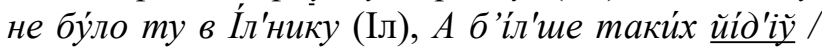

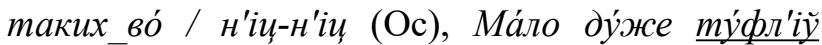
бу́ло (СНб); а також: бабиїв (Кузеля, 1908: 149), з дубровів (Рошкевич: 92; див. ще: Рабій-Карпинська, 2011: 72, 102; Ощипко, 1971: 176; Матвіяс, 1982: 56; AGB, VII (2): 80; m. 413). Закінчення -іў засвідчено в усіх бойківських говірках; паралельні форми баб // баб'уㅡ - у говірках с. Підліски та с. Матків (АУМ: к. 195), 'совий // 'сов'їу - у с. Плав'я; соў // 'сов'іў - у с. Жупани, Волосянка, Вишків, Підліски (АУМ: к. 196). Закінчення -іў в іменниках с.р. по́л'їу, се́ри'ï̌ зафіксувала I. Ощипко (Ощипко, 1971: 176).

Варіанте формотворення в Р. в. мн. ілюструють іменники ч. р.: госте́ Нб, НГс, Ор, Ос, СНб, Шм), го́стец (Лс), го́стий (Іл, Мт) го́c'm'ïy (Бг, Кр, Лк, Нб, Ур, Яв), го́c'm'iy̆ (Oc), ко́нец (Кр), ко́ниц (СНб), ко́н'їу (Лс), а також: го́c"u"iy̆ // го́сте $и ̆$ (Бт, Лс) (Ощипко, 1971: 176), хлопщий, хлопцей (Онишкевич, II: 341), па́л'ичий, nа́л'uеeй, палиі́́ (Онишкевич, II: 36), а також у записах кінця XIX ст. - гостий (Кузів, 1889: 286). Перевагу історичного закінчення -й ('оостиц,, 'коний) засвідчує АУМ (АУМ: к. 198, 199); форму 
х'лопииц засвідчено в говірках сіл Багнувате, Тур'€, Волосянка, Плав'я (АУМ: к. 194).

Сучасні діалектні тексти фісують здебільшого нормативне закінчення -ег̆ у множинних іменниках, спорадично збереглося історичне закінчення -й̆: л'yде́ НГс, Ор, СНб, Трл, Яв), л'уди́i (Лб Лс, Ор), двере́ (Кр) d'imé Сд, Шм, Ям), гроше́ Ул, Яв); пор. у записах від поч. ХХ ст.: гроший, сїний (Кміт, 1908: 83, 134), л'удий (Бт, Нб), д'і'тий (Бт) (Говори: 240, 242, 308). Про панівне формотворення на -ий в іменниках люди, діти, гроші (-й // -ей у говірках сіл Матків і Плав’я) свідчить АУМ (АУМ: к. 197, 200), паралельні закінчення в цих іменниках фіксує М. Онишкевич (Онишкевич, I: 194, 206, 422; дет. див.: Рабій-Карпинська, 2011: 72; Бандрівський, 1959: 6; Матвіяс, 1982: 56; Зубрицька, 1992: 6).

Сучасні діалектні записи свідчать про експансію літературного закінчення -ам у Д. в. мн. іменників ч. р.: брата́м (Ур, Яв), буйа́рам (Бг), го́c'm'áм (Бг, Глбк, Кр, СНб), го́c'ú'áм (Дн, Мж, Ур) (го́с'и'ом (Мж)), дружба́м (Бг), музика́нтам (Ур), нанашка́м (Ксм), похре́сникам (Ксм), ро́дчам (Кр, СНб), ро́дич'ам (Вч, Лб, Ос), сус'і́дам (Уp, Ям), хло́пи'ам (Бг, Кр, Ор, СНб), чолов'ікам (Вч) тощо, у множинних іменниках: d'ím'aм (Вч, Гл, Лс, СНб, Трл, Яв), л'у́д'ам (ВСт, Лп). Зафіксовано ненаголошене закінчення -ім в іменниках: ро́дич'iм (Дб, Сл, СНб, Трл), хло́nи'iм (Вч, Крш, Лп), бра́т'iм (ВСт, Лб, Рс), д'іве́р'ім, л'у́д'iм (ВСт), молод'ám'iм (Вч, Лб, Лп) а також: молодятїм, боярім (Кміт, 1908: 86, 93), бра́m('а́м // бра́т'ім (Онишкевич, I: 69), хло́пи'ом, хло́nч'iм, хло́nи'ам (Онишкевич, II: 341), бойк.: брат'ім, наддністр. брат'ом (Матвіяс, 1982: 48); брат'ім (сс. Орів, Багнувате, Вишків), б рат'ом (с. Тур'є), брат'ім // братам (сс. Суходіл, Ясень, Коростів, Бітля, Волосянка) (АУМ: к. 202), во л'ім (сс. Бітля, Матків) (АУМ: к. 201; див. ще: Бандрівський, 1959: 6; Ощипко, 1971: 176-177; Воронич, 2000; Радевич-Винницький).

Перевагу закінчення -ом (фонетичні варіанти

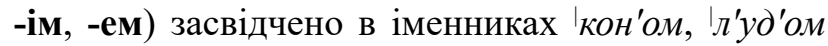
(АУМ: к. 203); як типові - -ом, -ім у Д. в. мн. відзначено в говірках центральної Бойківщини (Матіїв, 2013: 8), 'd'im'ом (Бт) (Говори: 242), d'im'ом (Онишкевич, I: 221). Як зазначив I. Керницький, форми Д. в. мн. іменників ч. р. на -омъ, -емъ (і фонетично змінені -умъ, -юмъ, -їмъ) в учительних євангеліях із Бойківщини у XVI - на поч. XVII ст. були загальновживані (Керницький, 1971: 404).
Як зазначає Ф. Жилко, закінчення -ім зрідка вживають на північних схилах Карпат, частіше давнє фонетично змінене закінчення -омъ - -ум (Жилко, 1955: 143), однак такого формотворення в сучасних діалектних текстах не виявлено; пор.: закінчення -ім, -ом, -ем, -ам в іменникові люди (Онишкевич, I: 422); див. також: -ім // -ам, спорадично -ем, -ом (AGB, VII (2): m. 414, 415).

Закінчення -ем у бойківських говірках зафіксовано дуже рідко: Тре́ба бу́ло $i$ з два́и'ат' спечи́ /

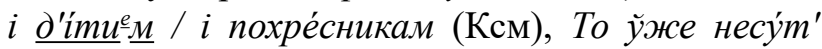
тот'і ж'інки́ д ха́m'i д'ітием б'іллого хл'і́ба (Мж), Цуке́рк'іу кладу́m / де хто урве́! / d'ітием де (Мж); див. ще: 500 людем (Кміт, 1936: 84; ще: Рабій-Карпинська, 2011: 72), що спричинено впливом контактних гуцульських і покутських говірок (див.: АУМ: к. 203).

Іменники назви істот у 3. в. мн. частіше зберігають форму давнього 3. в., що збігається з Н. в.: годува́ти д'і́mи (Гл), ма́ли д'і́ти (Нд), проси́ли d'ímu (Вч), збира́y̆ л'ýdu (Вч), го́c'm'am d'ǐyчáma (Oc), дайу́m пта́шки (Ул), пита́йут бики́ (Тр), ма́йе ко́н'i (Лб), в 'іd'ігна́ти ко́н'i (СНб), уббира́ли ко́н'i (Бг, Нб, НГс, Ос), прикраша́ли ко́н'i (Op, Трл, Ул), уйе́жут ко́н'i (Вч), упр'ага́ли ко́н'i (Іл, Кр, Ксм, Мл), на ко́н'і дава́ли (Кр) тощо, а також: прибра́ли ко́н'ï̆ (Лс; див. ще: Рабій-Карпинська, 2011: 72, 102; Ощипко, 1971: 177; Пура, 1960: 169), а також у записах від кінця XIX ст.: Oй дарую ти, дарую, Конички ти рихтую; Ой дарую ти, дарую, Я ти вівиї рихтую (Кузів, 1889: 301, 302), гостейки привитати, свашьки привитати (Кміт, 1908: 87, 94), свашечки поїти (Левинський,

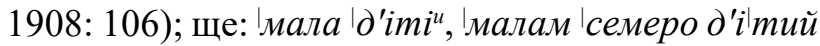
(Бт) (Говори: 240).

Збережено діалектні форми О. в. мн. - закінчення двоїни -ома, -іма, -има: в'ін'и'ома (Ур), йайи'о́ма (Глбк), колач'óма (Сл), колач'óма // колач 'е́ма (Нб), пал'и'о́ма (Вч), го́с'и'іма (Дб, Тр), го́с'm'iмa (ВСт, Кр), ро́дич’iмa (СНб), ру́ж'іма (Дб, Сл) тощо, а також: d'iу̌ча́m'iмa (Лб). Відзначено різне формотворення в мовленні говірконосія: Молода́ перетан'и'о́вуйе ўже молоди́иеў з ро́дич'iма / з д'іўча́тами / хло́пи'ами / го́с'и'ами (СНб). Як зазначив Д. Бандрівський, дуальне закінчення -о-ма проникає переважно в північні говірки Турківського району з наддністрянських (Бандрівський, 1959: 7; дет. див.: Рабій-Карпинська, 2011: 102-103; Ощипко, 1971: 177; Бевзенко, 1980: 227; Радевич-Винницький; Воронич, 2000; Матіїв, 2013: 8; АУМ: к. 204).

Закінчення -ми // -има засвідчено в множинних іменниках: дверми́ (Бк, ВСт, Лп), двери́ма (ВСт, Гл, Лс), гр'ішми (Бг, Лб, Мж, Рс), гроши́ма 
(Лп): Прийлии прида́не / там стойа́ли n’id дверми́_(Лп), Ну то́же б’ірв 'інком / тим в'іўсо́м у нас обс'іва́йут / гр'і́шми / коп'ійка́ми (Лб); також плечи́ма (ВСт, Вч, Лб, Тр). Закінчення -ми зафіксовано в іменникові кінь: ко́н'ми вора́ти (Вч), к'ін'ми йіхали (Ур), к'ін'ми ве́зли (Лб, Мл, Рс), с к'ін'ми йіхали (Мж), привезли́ к'ін'ми (Дб), йіхати к'ін'ми (Кр), а також: сан'мú (Oc): $Н y$ / йак ул'іт'і / то во́зом / а йак ўзим'í / то сан'мú (Oc); ще: $з$ телятьми, з ягнятьми (Кузів, 1889: 302).

Зафіксовано також фонетично видозмінені форми: го́с'т'іми (Pc), го́с'и'iми, ро́дич'iми (Тр), ружж'іми (Нб); плас'и'е́ми (Ур) колач'е́ми (Ксм); Ігост'еми // Ігост'іми (с. Орів) (АУМ: к. 204); пор.: бойк. Ігост'ами, наддністр. Ігост'ема, Ігост'іма (Матвіяс 1982: 48) пал'ииима, пал'иіма, па́л'ц'ами (Онишкевич, II: 36), го́с'u'aмu, го́с'u'iмu, го́с'u'iмa, го́с'й'іме, го́с'm'áми, г'ic'm'мú (Онишкевич, I: 172), а також stêzoikamye (Княжинський 1934: 16).

У говірках Турківщини іменники с. р. О. в. мн. мають кінцевий [i] після губного у флексії: Та / молоди́ı́ то́же з дру́жбоў // дру́жба пали́и'а така́ бу́ла краси́ва / така́ бл'ашча́ла з бл'а́хам’i / на шни́рок / ту на ру́ку / ну айа́ (Вч), Йак загра́ли n'id в 'їкнам'i / поча́лос'а вес'іл'á / y тог̆ час дес' че́рез за годи́ну / че́рез дв 'i / че́рез три приходи́ли го́с'т'і в 'ід молодо́го (НГс), Ходи́ли на в'ічерни́и'i c куде́л'ам'i (Мт).

Араїчне закінчення -и (ы) в іменниках О. в. (Рабій-Карпинська, 2011:72, 102; Жилко, 1955:143; Бандрівський, 1959: 6; Керницький, 1971: 404; Бевзенко, 1980: 225; Зубрицька, 1992: 19] виявлено лише у фольклорних текстах, пор.:

На добра́н'іч / на добра́н'іч д'іуччато́йка на н'іч // за воро́та / йáв 'ip зло́та / там т'а бу́ду ждати (Вч);

За вороти явір злотий, Там тя буду жьдати (Кміт, 1908: 83),

Гостинцем іде старостойка з бояри,

тихо, потихо пан старостойка з бояри (Кузів, 1889: 286), а також у записах від кінця XIX ст.: 3 бояри, під бояри молодими, стій зятю за воро́ти (Кузів, 1889: 286, 287), сьтьіü, зьámьу, за воро́ти (Гнатюк, 1908: 18), с хлопцฺи ся обіймали (Кузеля, 1908: 127).

У Місцевому в. мн. іменники I та II відмін мають закінчення:

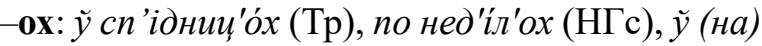
в 'íн'и'ох (ВСт, Кр), у Дрого́бичох (Нд), ў проп'їй'ох (Лб), на йе́й'ох (Вч), на ли́и'ох (Ям), на подв 'ірйох (Вч), по вес'і́л'ох (Рс, Трл), по пле́чох (ВСт, Лб) та ін.; а також: в чоботьох (Левинський, 1908: 119), по 'сел'ох (Яс), по 'пол'ох (Нб) (Говори: 306, 310), nо сухарн'ох (Яс) (Говори: 306), по вас"ілі'ох
(Матеріали'); див. ще: (AGB, VII (2): 80; m. 416, 417). Паралельні закінчення -ax // -ох в іменниках колишніх -јо- основ фіксує АУМ (АУМ: к. 205), закінчення -ох часто вживано в учительних євангеліях із території Бойківщини XVI-XVII ст. (Керницький, 1971: 405);

-ax: y̆ коси́и'ах (СНб), ў л'е́нтах (Лб), по ла́ўках (Мж), по ха́тах (Сд), у соро́чках (Мл), у вел'о́нах (Трл), уу (по) горн'á(é)тках (Оc, Рc), у в '̌нн'u'ах (Яв), у мунду́рах (Бк), на вес'їл'ах (ВСТ), на в 'і́кнах (Рc), по ро́дичах (Вч), при сва́тах (Трл) тощо;

-ix: по 'в'ікн'іх (Бт) (Говори: 241). Закінчення -іх в іменникові 'кон'іх (с. Ясень) засвідчує вплив говірок покутсько-гуцульського порубіжжя (АУМ: к. 205);

-их: на плечих (Нб) (Говори: 308), -ох // -их у східнобойківських говірках сіл Суходіл і Ясень (АУМ: к. 205).

Множинні іменники в М. в. демонструють варіантністьаке: -ax: y Pосо́xax, y перепóüiнах (Pc), y c'íнах (Сл), на гро́шах (Лп), на две́р'ах (Бг, Вч), на жо́рнах (Рc), на фл'іртах (Трл), по л'у́д'ах (Лб), у Сли́йках (Нб), -ох: на гру́д'ох (Бк, Мт), у Б'ісковичох (Нд); -ix: y сва́т'ix (Лб), на воро́т'ix (Мж), -их: на грýdux (Бг) тощо. У записах із Бойківщини від кінця XIX ст. засвідчено: при двеpix (Кміт, 1936: 84), на воротьох (Левинський, 1908: 119), по сїньох (Кузів, 1889: 283), по сїньох (Кміт, 1908: 89; Кузеля, 1908: 141). АУМ фіксує перевагу закінчення -ох, окрім говірок наддністрянсько-бойківського (с. Рибник) чи наддністрянсько-надсянсько-бойківського (с. Велика Сушиця та с. Біличі) порубіж; закінчення -ex виявлено в говірках с. Жупани та Ясень (АУМ: к. 206; див. ще: Свєнціцький, 1913: 125; РабійКарпинська, 2011: 73, 102-103; Жилко, 1955: 143; Бандрівський, 1959: 7; Бандрівський, 1960: 7; Воронич, 2000; Радевич-Винницький).

В обстежених говірках збережено двоїну іменників чоловічого роду в Н. в.: два хло́nа (Кр), два л'і́тра (Мл), два чолов'іка (СНб), шти́ри му́жа (Мж), три ме́тра (НГс), три дни (Вч, Ксм, Лб, Лк, Лп, Сл, СНб), дво́йе хл'і́ба (Тр, Трл), два́ бук'éma (Лc). Уживана дуальна архаїчна форма числівника $\partial$ ' $i$ у сполученні з іменниками ж. і с. роду: $\partial \varepsilon^{\prime} i$ де́рева (Лб), дв'i дру́шк’i (Мл, СНб), дв ’i в'ікна

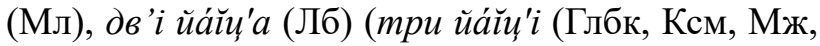
Сд)), ще: дв 'i бат'ки́ (Бк); дві яйці (Левинський, 1908: 102), дв'i 'ночи, два дни (Нб) (Говори: 308), хоч AGB акцентує на відсутності колишньої двоїни (AGB, VII (2): 82; дет. див.: Рабій-Карпинська, 2011: 73; Бандрівський, 1959: 7-8; Матїів, 2013: 8).

Висновки. На підставі зібраних сучасних діалектних текстів із Бойківщини, доступних 
етнографічних i фольклорних матеріалів від кінця XIX ст., діалектологічних джерел середини 50-60-х років XX ст. можна дійти висновку, що система словозміни іменників у бойківських говірках зберегла особливості діалектного формотворення, незважаючи на експансивний вплив літературної мови та контактних говорів, передусім наддністрянського.

В обстежених бойківських говірках функціюють архаїчні закінчення (передусім у парадигмі множини: - Н. в. - -е, також -ове; Д. в. та М. в. -ом, -ім, -ох, -іх; О. в. - двоїнне закінчення -ома, -има, -іма та ін.), окремі форми є рідковживаними (Р. в. - -е; Д. в. одн. із прийменником $\partial$, $i \partial, \kappa$; безприйменникові конструкції М. в., М. в. мн. - -iх тощо) чи не фіксованими (утрачено маркувальні для бойківських говірок морфологічні явища: закінчення -оў у Н. в. одн. іменників ж.р., -ум у Д. в. мн.; -и - в О. в. мн. тощо). Відзначено високий ступінь варіантности словоформ, зумовлених впливом літературної мови, перенесенням діалектних закінчень однієї відміни на іншу,

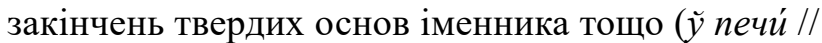
у печу́; хло́пчеви // хло́пщев'i; дру́жбоў // дру́жбом, пшени́и'оў // пшени́щеў // пшени́щейу; n'ісс'н'іў // n'icéн' тощо). Із-поміж закінчень, які збігаються 3 літературними, у деяких відмінках переважає нормативне (Д. в. одн. - -ові, -еві, рідко - -ови, -еви; Р. в. множинних іменників - -ей та ін.), а в інших - діалектне: давніші закінчення домінують, витісняючи навіть нові (О. в. одн. - -ом, рідко - -ем; М. в. одн. - -и, рідко - -і; М. в. мн. частіше -ох, рідко - -ах тощо). Продуктивними $\epsilon$ фонетично видозмінені закінчення (Р. в. одн. ж.р. - -иў; О. в. мн. - -іми, -еми тощо). У мовленні одного говірконосія виявлено дублетні словоформи: діалектні та закріплені літературною нормою закінчення.

Актуальність подальших студій $є$ перспективною $з$ огляду на потребу цілісно дослідити граматичну будову бойківських говірок, адже, за словами о. Юрія Кміта, «не одно ще скривають наші бойківські гори, що цікаве було б для людей науки» ${ }^{2}$.

\section{ПЕРЕЛІК НАЗВ НАСЕЛЕНИХ ПУНКТІВ І ЇХ СКОРОЧЕНЬ}

Бг - Богрівка Богородчаського р-ну Івано-Франківської обл.

Бк - Боберка Турківського р-ну Львівської обл.

Бт - Бітля Турківського р-ну Львівської обл.

ВСт - Верхня Стинава Стрийського р-ну Львівської обл.

Вч - Вовче Турківського р-ну Львівської обл.

Гл - Головецько Старосамбірського р-ну Львівської обл.

Глбк - Глибоке Богородчанського р-ну Івано-Франківської обл.

Дб - Доброгостів Дрогобицького р-ну Львівської обл.

Дв - Довжки Сколівського р-ну Львівської обл.

Дн - Дністрик Старосамбірського р-ну Львівської обл.

Зв - Завадка Сколівського р-ну Львівської обл.

Іл - Ільник Турківського р-ну Львівської обл.

Кр - Коростів Сколівського р-ну Львівської обл.

Крш - Крушельниця Сколівського р-ну Львівської обл.

Ксм - Космач Богородчанського району Львівської обл.

Лб - Либохора Турківського р-ну Львівської обл.

Лк - Луквиця Богородчанського р-ну Івано-Франківської обл.

Лп - Лопушанка Турківського р-ну Львівської обл.

Лс - Лосинець Турківського р-ну Львівської обл.

Мж - Міжгір'я Богородчанського р-ну Івано-Франківської обл.

Мл - Мельничне Турківського р-ну Львівської обл.

Мт - Матків Турківського р-ну Львівської обл.

Нб - Небилів Рожнятівського р-ну Івано-Франківської обл.

НГс - Нижне Гусне Турківського р-ну Львівської обл.

Нд - Недільна Старосамбірського р-ну Львівської обл.

Ор - Орів Сколівського р-ну Львівської обл.

Ос - Осмолода Рожнятівського р-ну Івано-Франківської обл.

Рс - Росохи Старосамбірського р-ну Львівської обл.

Сд - Саджава Богородчанського р-ну Івано-Франківської області

Сл - Сливки Рожнятівського р-ну Івано-Франківської обл.

СНб - Слобода-Небилівська Рожнятівського р-ну Івано-Франківської обл.

Тп - Топільниця Старосамбірського р-ну Львівської обл.

Тр - Труханів Сколівського р-ну Львівської обл.

\footnotetext{
${ }^{2}$ Кміт Ю. Впливи бойківського говору в проповідях О. А. Полянського. Літопис Бойківщини. Самбір, 1936. Рік VI. Ч. 8. C. 84 . C. $84-86$.
} 
Трл - Терло Старосамбірського р-ну Львівської обл.

Тш - Тишівниця Сколівського р-ну Львівської обл.

Ур - Урич Сколівського р-ну Львівської обл.

Шм - Шум'яч Турківського р-ну Львівської обл.

Яв - Явора Турківського р-ну Львівської обл.

Ям - Ямельниця Сколівського р-ну Львівської обл.

Яс - Ясень Рожнятівського р-ну Івано-Франківської обл.

\section{СПИСОК ВИКОРИСТАНИХ ДЖЕРЕЛ}

1. АУМ - Атлас української мови : у 3 т. Київ, 1988. Т. ІІ : Волинь, Наддністрянщина, Закарпаття і суміжні землі.

2. Бандрівський 1959 - Бандрівський Д. Деякі морфологічні особливості говірок Турківського району Львівської області. Дослідження і матеріали з украӥнської мови. Київ, 1959. Т. 2. С. 3-11.

3. Бандрівський 1960 - Бандрівський Д. Говірки Підбузького району Львівської області. Київ : Вид-во АН УРСР, 1960.

4. Бевзенко 1980 - Бевзенко С. Українська діалектологія. Київ, 1980.

5. Воронич 2000 - Воронич Г. Бойківський говір. Енциклопедія «Українська мова». Київ, 2000. URL: http:// litopys.org.ua/ukrmova/um.htm.

6. Гнатюк 1908 - Гнатюк В. Бойківське весїлє в Мшанци (Старосамбірського повіта). Матеріали до українськоруської етнології. Львів : Видання етнографічної комісії, 1908. Т. Х. С. 1-29.

7. Говори - Говори української мови : збірник текстів / відп. ред. Т. Назарова. Київ, 1977.

8. Жилко 1955 - Жилко Ф. Нариси з діалектології української мови : посібник для ф-тів мови й літ. пед. ін-тів. Київ : Рад. шк., 1955.

9. Зубрицька 1992 - Зубрицька М. І. Бойківська іменникова словозміна : автореф. дис. ... канд. філол. наук : 10.02.10 «Українська мова» / Київський державний педагогічний інститут ім. М. Драгоманова. Київ, 1992. 19 с.

10. Керницький 1971 - Керницький І.М. Деякі морфологічні риси бойківських і лемківських говірок за пам'ятками VI-VII ст. Праиі ХІІ Республіканської діалектологічної наради. Київ : Наук. думка, 1971. С. 402-411.

11. Кміт 1908 - Кміт Ю. Бойківське весїле в Гвіздци (Турчанського повіта). Матеріали до украӥнсько-руської етнології. Львів : Видання етнографічної комісії, 1908. Т. Х. С. 82-100.

12. Кміт 1936 - Кміт Ю. Впливи бойківського говору в проповідях о. А. Полянського. Літопис Бойківщини. Самбір, 1936. Рік VI. Ч. 8. С. 84-86.

13. Княжинський 1934 - Княжинський А. 3 бойківсько-лемківського пограниччя. Літопис Бойківщини. Самбір, 1934. Ч. 3. С. $9-20$.

14. Кузеля 1908 - Кузеля 3. Бойківське весїле в Лавочнім (Стрийського повіта). Матеріали до українсько-руської етнологіï. Львів : Видання етнографічної комісії, 1908. Т. Х. С. 121-150.

15. Кузів - Кузів I. Житє-буте, звычаі и обычаі горрского народу. Зоря. Львів, 1889. Ч. XVII. С. 282-287; Ч. XVIII. C. 299-302; Ч. XIX. C. $317-320$.

16. Левинський 1908 - Левинський В. Бойківське весїлє в Доброгостові (Дрогобицького повіта). Матеріали до українсько-руської етнології. Львів : Видання етнографічної комісії, 1908. Т. Х. С. 101-120.

17. Матвіяс 1982 - Матвіяс І. Групування говорів української мови. Структура украйнських говорів. Київ : Наук. думка, 1982. С. 3-68.

18. Матеріали - Матеріали діалектологічної експедиції зі села Бориня Турківського району Львівської области. Зберігаються у відділі української мови Інституту українознавства ім. І. Крип’якевича НАН України (Львів).

19. Матеріали ${ }^{1}$ - Матеріали діалектологічної експедиції зі села Коростів Сколівського районів Львівської области. Зберігаються у відділі української мови Інституту українознавства ім. І. Крип'якевича НАН України (Львів).

20. Матіїв 2013 - Матіїв М. Словник говірок центральної Бойківщини. Київ ; Сімферополь : Ната, 2013.

21. Мисевич 1937 - Мисевич О. Український весільний обряд у Бойківщині. Львів : Наш лемко, 1937.

22. MMAГ - Studia nad dialektologią ukraińską i polską. Z materialów b. Katedry Języków Ruskich UJ / oprac. i przygot. do druku M. Karaś. Zeszyty naukowe Uniwersytetu Jagiellońskiego. Kraków ; Warszawa, 1975. T. CCCLXXVI. Z. 44.

23. Рошкевич - Обряди і пісні весільні люду руського в селі Лолин Стрийського повіту. Зібрала О. Рошкевич. Опрацював I. Франко. 1886. Весілля : у 2 кн. / упор. М. Шубравська. Київ : Наук. думка, 1970. Кн. 2. С. 73-124.

24. ОЛА - Общеславянский лингвистический атлас. URL: www.slavatlas.org/puncts.html.

25. Онишкевич 1984 - Онишкевич М. Й. Словник бойківських говірок : у 2 ч. Київ, 1984.

26. Ощипко 1971 - Ощипко І. Система словозміни іменників у бойківському говорі. Прайі ХІІ Республіканської діалектологічної наради. Київ : Наук. думка, 1971. С. 170-179.

27. Пура 1960 - Пура Я.О. Деякі особливості синтаксису говорів Західної Дрогобиччини. Питання українського мовознавства. Львів, 1960. Кн. 4. С. 168-174.

28. Рабій-Карпинська 2011 - Рабій-Карпинська С. Бойківські говірки : збірник статей / ред. М. Лесів ; підгот. до друку В. Пилипович. Перемишль, 2011.

29. Радевич-Винницький - Радевич-Винницький Я. Бойківський говір. Енциклопедія сучасної України. URL: http://esu.com.ua/search_articles.php?id=36048.

30. Свєнціцький 1913 - Свєнціцький I. Бойківський говір с. Бітля. 3НTШ. 1913. T. CXIV. Кн. II. С. 129-153. 
31. Хібеба - Хібеба Н. Фонетичні особливості бойківських говірок Рожнятівщини. Вісник Запорізького національного університету. Серія «Філологічні науки». 2020. № 1. Ч. ІІ. С. 65-76.

32. Хібеба ${ }^{1}$ - Хібеба Н. Фонетичні особливості бойківських говірок Турківщини. Діалектологічні студії. 13 : збірник пам'яті Наталі Хобзей / відп. ред. П. Гриценко, Т. Ястремська. Львів : Інститут українознавства ім. І. Крип'якевича НАНУ, 2020. С. 334-359.

33. Яким 2002 - Яким М., Зубрицька М. 3 діалектології Бойківщини: іменникова словозміна, іменникова фразеологія. Дрогобич : Коло, 2002.

34. AGB - Atlas gwar bojkowskich : w 7 t. Wrocław ; Warszawa ; Kraków : Wyd. PAN, 1980-1991.

35. Schnaider 1911 - Schnaider J. Z życia górali nadłomnickich. Wesele w Jasieniu. Kwartalnik etnograficzny. Lud. 1911. T. XVII. Z. II-III. S. 151-161.

36. Schnaider 1912 - Schnaider J. Z życia górali nadłomnickich. Wesele w Perehińsku. Kwartalnik etnograficzny. Lud. 1912. T. XVIII. Z. I-IV. S. 141-153.

\section{REFERENCES}

1. Atlas ukrainskoi movy [Atlas of Ukrainian Language]. (1984-2001) (vol.1-3). Vol. 2: Volyn, Naddnistrianshchyna, Zakarpattia i sumizhni zemli [Volyn, Upper Dnister, Transcarpathian region and the neighboring lands]. Kyiv [In Ukrainian].

2. Bandrivskyi D. Deiaki morfolohichni osoblyvosti hovirok Turkivskoho raionu Lvivskoi oblasti. [Some morphological features of Turka district dialect, Lviv region]. Kyiv. Studies and materials on Ukrainian language, 1959, Vol. 2, pp. 3-11 [In Ukrainian].

3. Bandrivskyi, D. (1960). Hovirky Pidbuzkoho raionu Lvivskoi oblasti [Dialects of Pidbuzkyi district, Lviv region]. Kyiv, 104 p. [In Ukrainian].

4. Bevzenko, S. (1980). Ukrainska dialektolohiia [Ukrainian dialectology]. Kyiv [In Ukrainian].

5. Voronych, H. (2000). Boikivskyi hovir [The Boiko Dialect]. In The Ukrainian Language: Encyclopedia. Kyiv. P. 51-52. Kyiv [In Ukrainian].

6. Hnatiuk V. Boikivske vesilie v Mshantsy (Starosambirskoho povita). [Boyko wedding in Mshantsy (Starosambir district)]. Lviv. Materials to Ukrainian and Russ' ethnology. Publications of Ethnographical Commission, 1908, Vol. 10. pp. 1-29 [In Ukrainian].

7. Nazarova, T. (Chief Ed.), Dovhopol, S., Zaleskyi, A. \& Prylypko, N. (Eds.). (1977). Hovory ukrainskoi movy: zbirnyk tekstiv [Dialects of Ukrainian Language: a Collection of Texts]. Kyiv. 592 p. [In Ukrainian].

8. Zhylko, F. (1955). Narysy z dialektolohii ukrainskoi movy [Essays on Ukrainian dialectology]. Kyiv. 1955.314 p. [In Ukrainian].

9. Zubrytska M. I. Boikivska imennykova slovozmina. [Boyko noun word change]. Kyiv : Mykhailo Drahomanov State Pedagogical Institute in Kyiv, 1992, 19 p. [In Ukrainian].

10. Kernytskyi I. M. Deiaki morfolohichni rysy boikivskykh i lemkivskykh hovirok za pamiatkamy VI-VII st. [Some morphological features of Boyko and Lemko dialects after the documents of $6^{\text {th }} 7^{\text {th }}$ centuries]. Kyiv. Proceedings of $12^{\text {th }}$ Republican Dialectological Conference, 1971, pp. 402-411 [In Ukrainian].

11. Kmit Yu. Boikivske vesilie v Hvizdtsy (Turchanskoho povita). [Boyko wedding in Gnizdets (Turka district)]. Lviv. Materials to Ukrainian and Russ' ethnology. Publications of Ethnographical Commission, 1908, Vol. 10, pp. 82-100 [In Ukrainian].

12. Kmit Yu. Vplyvy boikivskoho hovoru v propovidiakh o. A. Polianskoho. [The Influences of Boyko dialect in sermons by Farther A. Polianski]. Sambir. Chronicles of Boyko Region, 1936, Vol. 6, Nr 8, pp. 84-86 [In Ukrainian].

13. Kniazhynskyi A. Z boikivsko-lemkivskoho pohranychchia. [From the Boyko and Lemko borderland]. Sambir. Chronicles of Boyko Region, 1934, Nr 3, pp. 9-20 [In Ukrainian].

14. Kuzelia Z. Boikivske vesilie v Lavochnim (Stryiskoho povita). [Boyko wedding in Lavochne (Stryi district)]. Lviv. Materials to Ukrainian and Russ' ethnology. Publications of Ethnographical Commission, 1908, Vol. 10, pp. 121-150 [In Ukrainian].

15. Kuziv I. Zhytie-butie, zvychai i obychai horskoho narodu.[Life and being of the mountain people]. Lviv. Zoria, 1889, Nr 17, pp. 282-287; Nr 18, pp. 299-302; Nr 19, pp. 317-320 [In Ukrainian].

16. Levynskyi V. Boikivske vesilie v Dobrohostovi (Drohobytskoho povita). [Boyko wedding in Dobrohostiv (Drohobych district)]. Lviv. Materials to Ukrainian and Russ' ethnology. Publications of Ethnographical Commission, 1908, Vol. 10, pp. 101-120 [In Ukrainian].

17. Matviias, I. (1982). Hrupuvannia hovoriv ukrainskoi movy. Struktura ukrainskykh hovoriv [The grouping of Ukrainian dialects. The Structure of Ukrainian dialects]. Kyiv. P. 3-68.

18. Materialy dialektolohichnoi ekspedytsii zi sela Borynia Turkivskoho raionu Lvivskoi oblasty. [Materials of Dialectological Expedition from a Borynia village of Tyrka district, Lviv region)]. Manuscript. Lviv. I. Krypyakevych Institute of Ukrainian Studies of the National academy of Sciences of Ukraine, Department of Ukrainian Language [In Ukrainian].

19. Materialy dialektolohichnoi ekspedytsii zi sela Korostiv Skolivskoho raioniv Lvivskoi oblasty. [Materials of Dialectological Expedition from a Korostiv village of Skole district, Lviv region)]. Manuscript. Lviv. I. Krypyakevych Institute of Ukrainian Studies of the National Academy of Sciences of Ukraine, Department of Ukrainian Language [In Ukrainian].

20. Matiiv, M. (2013). Slovnyk hovirok tsentralnoi Boikivshchyny [Dialect Vocabularly of the Central Boiko Region]. Kyiv, Simferopol. 602 p. [In Ukrainian].

21. Mysevych O. Ukrainskyi vesilnyi obriad u Boikivshchyni. [Ukrainian wedding ceremony in Boyko region]. Lviv : Our Lemko, 1937 [In Ukrainian]. 
22. Karas, M. (1975). Studia nad dialektologią ukraińską i polską. Z materialów b. Katedry Języków Ruskich UJ [Studies on Ukrainian and Polish dialectology. On a base of materials from Russian Language Department, Jagiellonian University]. Zeszyty naukowe Uniwersytetu Jagiellońskiego. Kraków, Warszawa. Vol. 376. 244 p. [In Polish].

23. Obriady i pisni vesilni liudu ruskoho v seli Lolyn Stryiskoho povitu. [Wedding ceremonies and songs of Russ people in Lolyn village of Stryi district]. Collected by O. Roshkevych, I. Franko. Kyiv, 1886. [In Ukrainian]. Vesillia [Wedding]. In 2 books. Compiled by M. Shubravska. Kyiv, Book 2, 1970, pp. 73-124 [In Ukrainian].

24. Obshcheslavianskyi lynhvystycheskyi atlas. [The All-Slavic Linguistic Atlas]. URL: www.slavatlas.org/puncts.html [In Russian].

25. Onyshkevych, M. (1984). Slovnyk boikivskykh hovirok [Vocabularly of Boiko dialect] (vols. 1-2). Kyiv [In Ukrainian].

26. Oshchypko I. Systema slovozminy imennykiv u boikivskomu hovori. [System of noun word change in Boyko dialect]. Kyiv. Proceedings of $12^{\text {th }}$ Republican Dialectological Conference, 1971, pp. 170-179 [In Ukrainian].

27. Pura Ya. O. Deiaki osoblyvosti syntaksysu hovoriv Zakhidnoi Drohobychchyny. [Some features of dialect syntax in the Western-Drohobych region]. Lviv. Questions of Ukrainian Language Studies, 1960, Book 4, pp. $168-174$ [In Ukrainian].

28. Rabii-Karpynska, S. (2011). Boikivski hovirky: zbirnyk statei [The Boiko dialects: a Collection of Works]. M. Lesiv (Ed.). V. Pylypovych (Compiler). Peremyshl. 189 p. [In Ukrainian].

29. Radevych-Vynnytskyi, Ya. (2004). Boikivskyi hovir [The Boiko dialect]. In Encyclopedia of Modern Ukraine. http://esu.com.ua/search_articles.php?id=36048 [In Ukrainian].

30. Svientsitskyi I. Boikivskyi hovir s. Bitlia. [Boyko dialect of Bitlia village]. Lviv. The Proceedings of Shevchenko Scientific Society, 1913, Vol. 114, Part 2, pp. 129-153 [In Ukrainian].

31. Khibeba N. Fonetychni osoblyvosti boikivskykh hovirok Rozhniativshchyny. [Phonetical features of Boyko dialects in Rozhniativ district]. Bulletin of Zaporizhzhia National University. Philological Sciences, 2020, № 1, Part 2, pp. 65-76 [In Ukrainian].

32. Khibeba N. Fonetychni osoblyvosti boikivskykh hovirok Turkivshchyny. [Phonetical features of Boyko dialects in Rozhniativ district]. Dialectological Studies. 13. Collection of works in memory of Natalia Khobzei. Edited by P. Hrytsenko, T. Yastremska. Lviv : I. Krypyakevych Institute of Ukrainian Studies of the National Academy of Sciences of Ukraine, 2020, pp. 334-359 [In Ukrainian].

33. Yakym M., Zubrytska M. Z dialektolohii Boikivshchyny: imennykova slovozmina, imennykova frazeolohiia. [From Dialectology of Boyko region: noun word change, noun phraseology]. Drohobych : A Circle, 2002 [In Ukrainian].

34. Rieger, J. (Ed.) (1980-1991). AGB - Atlas gwar bojkowskich [Atlas of the Boiko dialects] (vols. 1-7). Wrocław, Warszawa, Kraków [In Polish].

35. Schnaider J. Z życia górali nadłomnickich. Wesele w Jasieniu. [From the life of highlanders in Nadlomnica. Wedding in Yasenia]. Lud. Etnographic Quarterly, 1911, Vol. 17, Part 2-3, pp. 151-161.

36. Schnaider J. Z życia górali nadłomnickich. Wesele w Perehińsku. [From the life of highlanders in Nadlomnica. Wedding in Perehinsk]. Lud. Etnographic Quarterly, 1912, Vol. 18, Part 1-4, pp. 141-153. 